\title{
Teaching Professional Integrity: An Empirical Study on Engineering Students
}

\author{
https://doi.org/10.3991/ijep.v10i3.12013 \\ Spyridon Stelios $(\bowtie)$, Alexandros Christodoulou \\ National Technical University of Athens, Athens, Greece \\ stelioss@mail.ntua.gr
}

\begin{abstract}
In higher education there seems to be a 'gap' between the levels of undergraduate student expectation of being confronted by ethical issues in engineering work, and the amount of effective ethics education. Within this context, the purpose of this empirical research is to investigate engineering students' views on two issues: a) How vital professional ethics are in their field, and b) whether they believe that professional ethics must be a part of the syllabus in their School. Findings indicate that lecturers should make special reference to and strongly emphasize in class the value of an engineer's ethical responsibility. Furthermore, they need to spend a number of teaching hours on tackling problems in professional ethics as well as organize conferences, workshops, lectures and discussions, where the main speakers would be experienced engineers and academics. That way the technical and technological education incorporates more the responsibility of building professional integrity.
\end{abstract}

Keywords - Engineering ethics, higher education, empirical study, professionalism.

\section{Engineering Ethics in Higher Education}

The engineering sector has been making an invaluable contribution in today's technologically focused and digitalized society. This is also true with any individual's daily routine [1]. Engineering shapes, now more than ever, people's present and future by referring to fundamental objectives of their lives such as safety, prosperity and protection. Society's need for achieving these objectives combined with the high level of risk that is inherent in engineering practice are revealing of how important professional ethics are to engineers. Moreover, the nature of these key objectives to a great extent determines the qualities that any professional should have. These qualities, being to some degree character traits, contribute to the successful absorption of engineering products and services into society. With all of the above put together, it becomes clear that the main challenge faced by engineers today is to harmoniously incorporate into their professional behavior (and why not into their character) practical qualities of the profession (e.g. efficiency) and combine them in an effective manner with the theoretical ethical framework established under official codes of conduct. 
Before entering the professional arena, engineers are university students. In this early, yet crucial, period in their life, teaching of proper professional conduct should play an important role. In higher education, engineering ethics has been studied by various researchers [2] [3] [4] [5] [6] [7]. In an empirical study, conducted at the University of Stanford, [8] administered a questionnaire to investigate the expectations associated with professional ethics in engineering students and also the views of practicing engineers based on their work experience. According to [8] (pp. 518-519), there is mainly a pedagogical side to this issue. The way ethics courses are designed and prepared may reflect, on one hand, the perspective engineers-to-be having about the content of the curriculum and, on the other hand, experiences and views of former engineering students of issues they are faced with in the course of their career. [8] [9]' findings reveal a 'disconnection', or 'gap' between the levels of undergraduate student expectation of being confronted by moral questions in their work, and the amount of effective ethics education. They reveal also the necessity for lecturers to assist students clarify the concept of what it means to be a responsible engineer today.

This is further supported by [10] who found that engineering students place a high value on the importance of ethics in their education "tearing down the myth" that they are only interested in technical fields of study. In addition, [11] concluded that students value ethics instruction since it could offer insight on how to deal with ethical dilemmas in the workplace.

\section{Research Identity}

\subsection{Objectives}

The purpose of this empirical research is to investigate engineering students' views on two basic questions:

1. How vital professional ethics are in their field of (future) work

2. Whether they believe that professional ethics must be a part of the syllabus in their School.

Moreover, the fact that the survey population are students of the School of Naval Architecture \& Marine Engineering (S.N.A.M.E.) of the National Technical University of Athens (N.T.U.A.) has been an opportunity to also study the role that a technical University plays in helping students build professional integrity. Of course the fact that this study was conducted in only one out of nine Schools of the N.T.U.A. inevitably limits the range of any conclusion. Nevertheless though, it could offer a glance at the ethical aspects of the engineering studies spectrum. Finally, it should be mentioned that 'Ethics' is integrated within an 'Introduction to Philosophy' course $\left(1^{\text {st }}\right.$ semester) and is not a distinct course in the S.N.A.M.E. curriculum. 


\subsection{Sample and method}

Each year the School admits about 120 new students. The survey sample was composed of 100 S.N.A.M.E. students during the academic year 2016-17. Availability sampling was used. The sample consists of students who used the facilities of the School's pc-lab. The majority of the respondents were undergraduates whereas recent graduates (having graduated 0 to 2 years ago) were also included. A main aim was that the sample would be composed of students from all semesters. Finally, questionnaires were filled out at different time and date and were provided either online or in person.

\subsection{Questionnaire}

In designing the questionnaire, we followed the principle that the questionnaire should be formulated in a simple way. Thus, it was a rather small one, meaning that it was designed in a way not to require over 45 minutes for respondents to fill it out [12]. The questionnaire was in Greek, translated partially from English and linguistically validated. Discussions between researchers and lecturers were conducted about the topic of this study and on a first draft of the questionnaire (face validity). Furthermore, the content validity of the questionnaire was assessed through an initial exploratory interview with 10 S.N.A.M.E. students (pre-test).

The questionnaire consisted of two parts and was filled out anonymously. In Part A the selection of questions is based mostly on [8]'s students' questionnaire. It concerned questions regarded as more relevant to the survey's objective. In Part B students were asked to respond to 3 questions using a Likert scale. The first 2 dealt with the relation between studies and professional integrity following graduation. The third question is specially designed for respondents to be faced with a hypothetical dilemma and then examine the way they would choose to handle it. After that, they were given the choice to add, comment or clarify whatever they felt was necessary. Finally, for further validation, the scores of [8]'s study (covering all years and students) were compared with the scores of this study (see Table 1). By comparing the percentages of both studies, one observes that in most questions the ranking coincides and in some cases the percentages are very close.

\section{$3 \quad$ Results and Analysis}

Questions A4, A5, A6, A7, A8, A10 \& B2 are taken from [8] (pp. 539-540) where the corresponding questions are S5, S6, S8, S10, S15, S19 \& S13. Table 1 shows all answers in the form of percentages. Only the new questions are included in the Table. For comparative purposes [9]'s respondents' rates are also presented in brackets. 
Table 1. Questions and respondents data (data from [8])

\begin{tabular}{|c|c|}
\hline Questions & Respondents Data \\
\hline \multicolumn{2}{|r|}{ Part $A$} \\
\hline A1: Gender & Male: $76 \%$, Female: $24 \%$ \\
\hline A2: Age & 19-24: $62.9 \%, 24-30: 36,1 \%,>30: 1 \%$ \\
\hline A3: Study level & Undergraduate: $78 \%$, Graduate: $22 \%$ \\
\hline A4 (S5) & $\begin{array}{l}\text { Yes: } 95 \% \text {, No: } 5 \% \\
\text { (Yes: } 77.7 \%, \text { No } 22.3 \%)\end{array}$ \\
\hline A5 (S6) & $\begin{array}{l}\text { Yes: } 83 \% \text {, No: } 10 \% \text {, No opinion: } 7 \% \\
\text { (Yes: } 64.7 \% \text {, No: } 10 \% \text {, No opinion: } 4 \% \text {, No answer: } 21.3 \% \text { ) }\end{array}$ \\
\hline A6 (S8) & $\begin{array}{l}\text { Yes: } 52.5 \% \text {, No: } 47.5 \% \\
\text { (Yes: } 31 \% \text {, No: } 69 \%)\end{array}$ \\
\hline A7 (S10) & $\begin{array}{l}\text { Yes: } 86.9 \% \text {, No: } 9.1 \% \text {, No opinion: } 4 \% \\
\text { (Yes: } 85 \% \text {, No: } 9.2 \% \text {, No opinion: } 5 \% \text {, No answer: } 0.6 \% \text { ) }\end{array}$ \\
\hline A8 (S15) & $\begin{array}{l}\text { Yes: } 50 \% \text {, No: } 32.7 \% \text {, No opinion: } 17.3 \% \\
\text { (Yes: } 45.5 \% \text {, No } 53.9 \% \text {, No opinion: } 0 \% \text {, No answer: } 0.6 \% \text { ) }\end{array}$ \\
\hline $\begin{array}{l}\text { A9: Based on your experience so far as a } \\
\text { student, which of the following would you } \\
\text { say is most important for an engineer these } \\
\text { days? }\end{array}$ & $\begin{array}{l}\text { a) To be responsible, professional and aware of the ethical } \\
\text { obligations and responsibilities: } 80.8 \% \\
\text { b) To have excellent knowledge of their subject, which may } \\
\text { not necessarily be combined with professionalism and } \\
\text { specific moral principles: } 19.2 \%\end{array}$ \\
\hline A10 (S19) & $\begin{array}{l}\text { Yes: } 35.4 \% \text {, No: } 46.5 \% \text {, No opinion: } 18.1 \% \\
\text { (Yes: } 14.7 \% \text {, No: } 84,4 \% \text {, No opinion: } 0 \% \text {, No answer: } 0.9 \% \text { ) }\end{array}$ \\
\hline \multicolumn{2}{|r|}{ Part B } \\
\hline $\begin{array}{l}\text { B1: Suppose that all necessary knowledge } \\
\text { about ethical dilemmas that an engineer may } \\
\text { be faced with, and the appropriate ways to } \\
\text { handle and tackle them were made available } \\
\text { during the period of her studies. How much, } \\
\text { in your opinion, this would help that engi- } \\
\text { neer's career? }\end{array}$ & $\begin{array}{l}\text { Not at all: } 1 \% \text {, A little bit: } 5 \% \text {, Somewhat: } 22 \% \text {, A good } \\
\text { deal: } 42 \% \text {, A great deal: } 30 \%\end{array}$ \\
\hline B2 (S13) & $\begin{array}{l}\text { Not at all: } 10 \% \text {, A little bit: } 40 \% \text {, Somewhat: } 33 \% \text {, A good } \\
\text { deal: } 13 \% \text {, A great deal: } 4 \% \\
\text { (Not at all: } 18.7 \% \text {, A little bit: } 34.7 \% \text {, Somewhat: } 30 \% \text {, A } \\
\text { good deal: } 12.3 \% \text {, A great deal: } 3.5 \% \text { ) }\end{array}$ \\
\hline $\begin{array}{l}\text { B3: Assuming that you work as a naval } \\
\text { architect and you have been assigned with } \\
\text { the safety inspection of a newly built vessel. } \\
\text { Your services will be highly re-munerated, } \\
\text { provided that the inspection is completed } \\
\text { before a specific date. You reached that date } \\
\text { and you have carried out } 80 \% \text { of the individ- } \\
\text { ual checks, therefore you CANNOT fully } \\
\text { guarantee that the vessel is safe. Considering } \\
\text { that the major part of checks has been carried } \\
\text { out and also taking account of the high } \\
\text { remuneration you would receive, would you } \\
\text { grant approval? } \\
\text { If you would like to note or add something to } \\
\text { your answer please do so here: }\end{array}$ & $\begin{array}{l}\text { Definitely not: } 50 \% \text {, Maybe: } 37 \% \text {, Probably: } 11 \% \text {, Definite- } \\
\text { ly: } 2 \%\end{array}$ \\
\hline
\end{tabular}




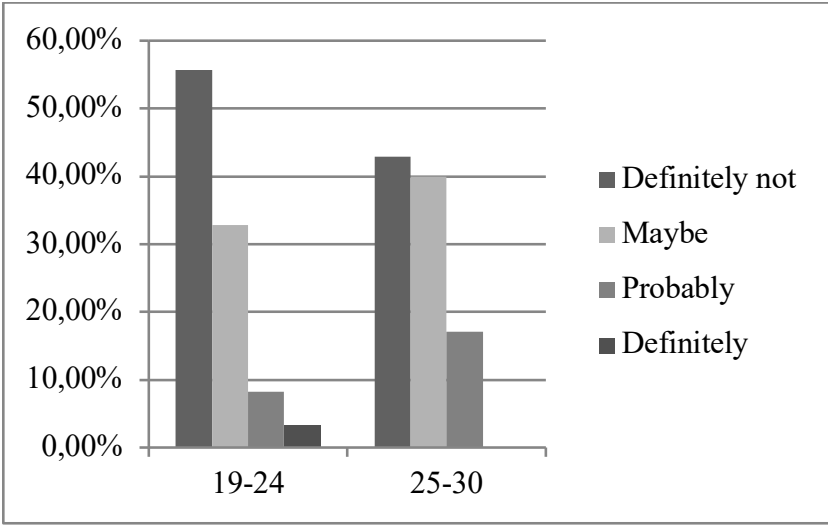

Fig. 1. Cross-tabulation analysis of questions B3 and A2

Figure 1 presents the results of cross-tabulating question B3 with students' age groups. A $55.7 \%$ of students aged between 19 and 24 replied "definitely not" to that question, followed by "maybe". In age group 25-30 (more graduates in this group), a higher percentage of "maybe" and "probably" is observed.

All data, and especially those presented in Table 1 and Figure 1, demonstrate the success of this methodological approach in evaluating the importance of ethical education at students' and school's curriculum level. The data obtained seem to verify also the contribution of this approach compared to the latest evidence available on this subject (see in particular [6] [10] [11]).

The main findings obtained from the respondents' answers are outlined below:

1. The vast majority of S.N.A.M.E. students consider professional ethics-related dilemmas as an issue with which they will be faced one or several times in their postgraduation career. They also consider professional integrity as a necessary quality for any engineer. A quality that goes along with knowledge and training (questions A5, A9 and B1).

2. Students' views as reflected in their answers to questions exploring whether and to what extent the topic of professional ethics is raised by teachers during lectures (questions A6, A8 and A10) are split. This leads to the conclusion that professional ethics issues are raised by only a portion of teachers and, most probably, not systematically so.

3. The view that professional ethics should become a component of engineering courses is clearly predominant. However, most students believe that the university's contribution ranges from average to little (questions A7 and B2).

4. None of the three years' students responded to question B3 (question - scenario) with "probably" or "definitely". Moreover, $88 \%$ of that specific students' group responded in question A9 that the most important quality of a new engineer is responsibility and professionalism, showing awareness in terms of ethical obligations and responsibilities. What can be drawn from these data is that junior students see professional ethics as a quality that goes hand in hand with good engineering prac- 
tice. At the same time, a relatively looser approach as to professional ethics is observed in majors.

5. In question A9 the most common response is clearly the one emphasizing engineering ethical behaviour. When cross-tabulating this question with question A3, we observe that undergraduate students gave this response at a percentage of $83.1 \%$ whereas the percentage in the same response given by graduates is significant but not as high $(72.7 \%)$.

6. An interesting differentiation between undergraduates and graduates can be found in their responses to question B3. More specifically, while more than half of the undergraduates $(53.8 \%)$ responded "definitely not", the majority of graduates (45.4\%) replied "maybe", indicating a hesitation towards the two decisions. "Probably" is also higher among graduates compared to that of undergraduates. As shown above, when cross-tabulating question B3 with students' age groups, a statistically similar picture emerges.

Below are some further observations based on the students' responses to question B3 (open-ended question):

1. Responses "definitely not" and "maybe" are identified as somewhat "adjustable" as 1 student who replied "definitely not" and 5 who replied "maybe" further clarified that they might give a different reply under other conditions (that is, the first one might reply "maybe" and the other five "definitely not".)

2. Those students who replied "definitely not" stated, among other things, that: a) if they granted some approval and an accident occurred, this might have a negative impact on their reputation as engineers b) in case of a damage, coverage would be more expensive than any necessary preventative action, and c) a naval architect's ethical behaviour does not depend only on the academic background obtained at the University, but is also associated with both work experience and that person's honesty. Out of the 3 graduates that responded to the open-ended question, 2 of them answered 'Maybe' stating a) "This has to be approved only by me? If so, this is going to be more difficult" and b) "The important here is to know what type of checks is included in the $20 \%$ that have not been carried out."

\section{Conclusion and Proposals}

Based on the findings, three key conclusions may be drawn:

1. Engineering students see professional ethics as a critical factor in their profession and the related ethical behaviour as a quality that any engineer must have. They aspire to be able to anticipate possible risks in any non-ethical choice that they would make and deal with any ethical dilemmas properly and maturely.

2. The majority of engineering students of S.N.A.M.E. School believe that professional ethics should be a component of engineering courses in their School. At the same time, they find that professional ethics are not sufficiently emphasized. 
3. As students grow in age and move on to the senior years of their studies, professional ethics seem to take a slightly downward trend in terms of value and emphasis. Instead of further developing a sense of professional integrity as they get a more in-depth knowledge of their discipline, that sense is actually weakened. Maybe they gradually become more cynical about these issues.

Even though results cannot be generalized with statistical precision, these initial conclusions indicate that every technical School should continue to work on building professional integrity in its students by emphasizing the value conferred on an ethically responsible engineer. In addition to knowledge and specialization, students should have competences that will enable them to address any professional ethics-related issue raised in the course of their business in a mature and effective manner. Measures to be taken in that direction, officially or unofficially, are, inter alia:

1. Ensuring that professional ethics gain ground in the syllabus through new courses that will explore various aspects

2. Lecturers should make special reference to and strongly emphasize in class the value of an engineer's ethical responsibility. Students' responses indicate that this has somewhat been applied, but not to a satisfactory extent

3. Organization of conferences, workshops, lectures and discussions, where the main speakers would be experienced engineers and academics

4. Spending a number of teaching time on tackling problems in professional ethics. Thus, students will be invited to submit their concerns using selected examples of ethical dilemmas, similar to those found in the questionnaire of this survey.

In conclusion, technical and technological education must incorporate the responsibility to build professional integrity which in turn, guarantees the much-needed social goods of progress, prosperity and safety.

\section{Acknowledgement}

We thank Professor Robert McGinn for his kind permission to use the questionnaire for our study and the anonymous reviewers for their careful reading of our manuscript.

\section{References}

[1] Sedelmaier, Y. \& Landes, D. (2017). How can we find out what makes a good requirements engineer in the age of digitalization? International Journal of Engineering Pedagogy, 7(3), 147-164. https://doi.org/10.3991/ijep.v7i3.7424

[2] Bird, S. J. \& Sieber, J. E. (2005). Teaching Ethics in science and engineering: Effective online education. Science and Engineering Ethics, 11(3), 323-328. https://doi.org/10.1007/ s11948-005-0001-8

[3] Newberry, B (2004). The dilemma of ethics in engineering education. Science and Engineering Ethics, 10(2), 343-351. https://doi.org/10.1007/s11948-004-0030-8 
[4] Hollander, R. D. (2005). Ethics education at NSF. Science and Engineering Ethics 11(3), 509-511. https://doi.org/10.1007/s11948-005-0021-4.

[5] Aközer, M. \& Aközer, E. (2017). Ethics teaching in higher education for principled reasoning: A gateway for reconciling scientific practice with ethical deliberation. Science and Engineering Ethics, 23(3), 825-860. https://doi.org/10.1007/s11948-016-9813-y

[6] Monteiro, F. (2017). The students' perspective contribution: Rethink the ethical education of engineering students. International Journal of Engineering Pedagogy, 7(2), 22-35. https://doi.org/10.3991/ijep.v7i2.6819

[7] Maher, P.A. Bailey, J. M. \& Tucka, A. M. (2018). Teaching process skills to pre-engineers using situated learning - A case study. International Journal of Engineering Pedagogy, 8(5), 121-147. https://doi.org/10.3991/ijep.v8i5.9036

[8] McGinn, R. E. (2003). "Mind the gaps": An empirical approach to Engineering Ethics, 1997-2001. Science and Engineering Ethics, 9, 517-542. https://doi.org/10.1007/ $\underline{\mathrm{s} 11948-003-0048-3}$

[9] McGinn, R. E. (2018). The Ethical engineer: Contemporary concepts and cases. Princeton University Press: Princeton, New Jersey. https://doi.org/10.1111/meta.12356.

[10] Otieno, W., \& Kumar, N. A situated learning ethics instruction model for engineering undergraduate students. Proceedings of the Frontiers in Education Conference (FIE), October 21-24 2015, El Paso, Texas, USA, pp. 1159-1163. https://doi.org/10.1109/ fie.2015.7344214

[11] Rottmann, C., Reeve, D., Sacks, R., \& Klassen, M. Engineering ethics education: More than a CEAB requirement. Proceedings of the Canadian Engineering Education Association (CEEA), May31-June 3 2015, McMaster University, Canada, pp. 1-4. https://doi.org/10.24908/pceea.v0i0.5809

[12] Herzog, A. R. \& Bachmann, J. G. (1981). Effects of questionnaire length on response quality. Public Opinion Quarterly, 45(4), 549-559. https://doi.org/10.1086/268687.

\section{$7 \quad$ Authors}

Dr Spyridon Stelios is a teaching and research associate at the National Technical University of Athens (NTUA). He lectures in schools of NTUA and he has participated in various research projects. His main interests are in the area of applied ethics, epistemology and experimental philosophy. Email: stelioss@central.ntua.gr

Alexandros Christodoulou is a graduate of the school of Naval Architecture and Marine Engineering of National Technical University of Athens (year of graduation: 2018). Since then, he has had a professional presence in the shipping industry as a naval engineer, having worked for companies that are active in that field.

Article submitted 2019-10-25. Resubmitted 2020-01-24. Final acceptance 2020-01-25. Final version published as submitted by the authors. 